\title{
Efficacy of different bio-pesticides against sucking pests of okra (Abelmoschus esculentus L. Moench)
}

\author{
Suraj Sarkar ${ }^{1 *}$, Sandip Patra ${ }^{2}$ and A. Samanta ${ }^{3}$ \\ ${ }^{1}$ Cooch Behar Krishi Vigyan Kendra, Uttar Banga Krishi Viswavidyalaya, Pundibari, Cooch Behar-736 165, (West \\ Bengal), INDIA \\ ${ }^{2}$ Division of Crop Protection, ICAR Research Complex for NEH Region, Umiam -793103 (Meghalaya), INDIA \\ ${ }^{3}$ Department of Agricultural Entomology, Bidhan Chandra Krishi Viswavidyalaya, Mohanpur, Nadia -741252 (West \\ Bengal), INDIA. \\ *Corresponding author: surajbckv2007@gmail.com
}

Received: July 2, 2015; Revised received: December 10, 2015; Accepted: March 3, 2016

\begin{abstract}
The field experiment was carried out in the pre-kharif season of 2013 at Bidhan Chandra Krishi Viswavidyalaya, Kalyani, Nadia, West Bengal, India to evaluate the efficacy of different bio-pesticides against sucking pests of okra. The experiment was laid out in randomized complete block design with three replications for each treatment. The treatments viz. annonin 1\% EC, karanjin 2\% EC, Azadirachtin 1\% EC, Metarrhizium anisopliae, Verticillium lecanii , Beauveria bassiana , Bacillus thuringiensis var Kurstaki, spinosad $45 \%$ SC and imidacloprid $17.8 \%$ SL were applied at 15 days interval starting from seedling stage when whitefly and jassid infestation started. Results revealed that the overall best performance of insecticides against whitefly was recorded in imidacloprid treated plots with lowest mean population of whitefly ( 3.91 whitefly/15 leaves) followed by karanjin (4.16 whitefly/15 leaves) and azadirachtin (5.16 whitefly/15 leaves while the order of efficacy aginst jassid were imidacloprid (15.27 jassids/15 leaves) > karanjin (33.91jassids/15leaves)>azadirachtin(40.38jassids/15leaves). Effectiveness of test insecticides on the yield of okra wasspinosad $>B t>B$. bassiana $>$ azadirachtin $>$ imidacloprid $>$ annonin $>$ karanjin $>M$. anisopliae.
\end{abstract}

Keywords: Annonin, Azadirachtin, Jassid, Karanjin, Whitefly.

\section{INTRODUCTION}

Okra or Ladies finger or Bhendi, Abelmoschus esculentus L. Moench (Malvaceae) is a good representative of the vegetables grown throughout the country along with other crops. It is important vegetable of the tropical countries and most popular in India. In India, the area under okra cultivation is 5.30 lakh hectare and its production is 63.5 lakh tonnes with an average yield of 12.0 MT/ha during 2012-13 (Anonymous, 2013). One of the major constraints in okra cultivation is its susceptibility to a number of insect pests during the various phases of its growth. Though, okra shoot and fruit borer appeared to be the most serious inflicting 45 $-57.1 \%$ damage to fruits (Srinivasan and Krishnakumar, 1983) but recently the sucking pests are becoming major pests under changing climatic condition coupled with application of injudicious and spurious pesticides which causes considerable yield loss to the various commercial crops. Jassid and whitefly are the most limiting factor for production of marketable fruit yield of okra. The crop must be protected from the attack of insect pests particularly sucking pests. Seasonal incidence of different pests has been studied by many workers (Kashyap and Verma 1982; Mahmood et al., 1988) who reported that okra is infested severely by many pests during warm and rainy season such as leaf hopper and shoot and fruit borer (Gandhale et al., 1987; Clement and David 1989; Madan et al., 1996). It is reported that the pests like jassid, shoot and fruit borer and leaf roller can cause up to $69 \%$ yield loss in okra (Rawat and Sahu,1983). To mitigate the losses due to these pests, a huge quantity of pesticides is used in okra that led to the problem of development of resistance, resurgence, environmental pollution. Therefore, the present study was undertaken to evaluate the efficacy of different bio-pesticides for eco-friendly management of sucking pests of okra.

\section{MATERIALS AND METHODS}

The field experiment was carried out in the pre-kharif season of 2013 at C Block Farm of Bidhan Chandra Krishi Viswavidyalaya, Kalyani, Nadia, West Bengal, India to evaluate the efficacy of different bio-pesticides against sucking pests of okra. The experiment was laid out in randomized complete block design with three replications for each treatment. Crop was sown in the plot size of $3 \mathrm{~m} \mathrm{x} 4 \mathrm{~m}$ area with $45 \mathrm{~cm}$ x $60 \mathrm{~cm}$ spacing. The crop was raised with recommended management practices except plant protection measures. The treatments viz. annonin 1\% EC ( $2 \mathrm{ml} / \mathrm{l})$, karanjin 
$2 \%$ EC (2ml/1), Azadirachtin $1 \%$ EC $(2 \mathrm{ml} / 1)$, Metarrhizium anisopliae - CFU Count $1 \times 10^{\wedge} 8 / \mathrm{g}(5$ $\mathrm{g} / \mathrm{l})$, Verticillium lecanii- CFU Count $1 \times 10 \wedge 8 / \mathrm{g}$ (5g/l), Beauveria bassiana - CFU Count $1 \times 10^{\wedge} 8 / \mathrm{g}$ (5g/l), Bacillus thuringiensis var Kurstaki-18,000 IU/ $\mathrm{mg}(2 \mathrm{~g} / \mathrm{l})$, spinosad $45 \% \mathrm{SC}(1 \mathrm{ml} / \mathrm{l})$ and imidacloprid $17.8 \% \mathrm{SL}(0.3 \mathrm{ml} / \mathrm{l})$ were applied at 15 days interval starting from seedling stage when whitefly and jassid infestation started. Spraying were done with pneumatic knapsack sprayer using spray fluid @ 5001/ ha.Observations were taken on 1 day before the spray as pretreatment and successive observations were recorded on 1, 3, 7 and 14 days after each spray. Whitefly and jassid were counted from randomly selected 5 tagged plants/plot covering top, middle and lower leaves/plant. The critical difference (CD) at $5 \%$ level of significance was worked out from the data of mean population before the spraying and subsequent various days' intervals after spraying.

\section{RESULTS AND DISCUSSION}

Efficacy of insecticides against whitefly: Results (Table 1) revealed that there was no significant difference of whitefly population among the treatments before spraying. After first spray lowest mean population of whitefly (2.41 whitefly/15 leaves) was observed in imidacloprid treated plots followed by karanjin $(3.58$ whitefly/15 leaves) and azadirachtin (4.33 whitefly/15 leaves). Among the microbial pesticides, M. anisopliae and $V$. lecanii were moderately effective with mean population of 5.42 and 5.74 whitefly/15 leaves, respectively. Whereas, in untreated (control) plots it was 10.83 whitefly/15 leaves. Highest percentage reduction of whitefly population over control was also recorded in imidacloprid treated plots (77.74\%) followed by karanjin (66.94\%) and azadirachtin $(60.01 \%)$. Among the microbials, B. bassiana (25.39\%) and B. thuringiensis var Kurstaki (26.13\%) were not effective in reducing the whitefly population but these were found to be superior over control.

During second spray, results (Table 2) revealed that imidacloprid recorded minimum population of whitefly (4.83whitefly/15 leaves) followed by azadirachtin (7.24 whitefly/15 leaves). $V$. lecanii and karanjin were at par with spinosad treated plots with $8.25,8.00$ and 8.49 whitefly/15 leaves, respectively. M. anisopliae, B. bassiana and B.t. were found to be less effective in reducing whitefly population but were superior over control. Similar trend was observed in percent reduction of whitefly population over control as in first spray.

After final spray (Table 3) lowest mean population of whitefly (2.33 whitefly/15 leaves) was observed in imidacloprid treated plots followed by karanjin (4.75 whitefly/15 leaves) and azadirachtin (5.16 whitefly/15 leaves). Spinosad and annonin provided moderate control with 6.33 and 6.91 whitefly/15 leaves, respectively. Highest percentage reduction of whitefly population over control was also recorded in imidacloprid treated plots $(89.60 \%)$ followed by karanjin $(78.80 \%)$ and azadirachtin $(76.97 \%)$.

Pooled data (Table 7) of three consecutive sprays revealed that imidacloprid provided best control with lowest mean population of whitefly (3.91 whitefly/15 leaves) followed by karanjin (4.16 whitefly/15 leaves) and azadirachtin (5.16 whitefly/15 leaves). $M$. anisopliae, $V$. lecanii and B.t. were less effective in reducing population of whitefly with mean population of $10.41,8.41$ and 11.24 whitefly/15 leaves, respectively. Highest percentage reduction of whitefly population over control was also recorded in imidacloprid treated plots (79.60\%) followed by karanjin $(70.93 \%)$ and azadirachtin $(68.26 \%)$.

Present findings are in close conformity with the results of Raghuraman and Ajanta (2011) who reported that imidacloprid 17.8\% SL@80 gm a.i./ha significantly suppressed whitefly and leafhopper populations, and consequently increased the yield in okra. Borkar et al. (2012) who reported that application of neem oil $1 \%$ amalgamated as the most effective treatment in recording the minimum population of whitefly. Hajeri et al. (2007) reported that the neem based formulation achook was found to be effective insect repellent causing reduction of whitefly population to $0.89 /$ plant and disease incidence to $5.0 \%$. Leeuwen et al. (2006) observed that systematically applied spinosad was effective against whitefly nymphs at doses as low as 2 $\mathrm{mg}$ active ingredient per plant, which is in agreement with our present findings. $V$. lecanii provided moderate control against whitefly which is similar with the findings of Negasi et al. (1998) who reported that Isolate FR20 ( $V$. lecanii) was the most pathogenic to third-instar larvae. M. anisopliae was less effective in reducing population of whitefly which is analogous with the findings of Bairwa et al. (2006) but conflicting with the findings of Malsam and Kilian (1998). The efficacy of $B$. bassiana against whitefly is disagreed with the findings of Islam et al. (2011) and Maketon et al. (2009).

Efficacy of insecticides against jassid: There was no significant difference of jassid population among the treatments before spraying (Table 4). During first spray, imidacloprid recorded lowest mean population (4.91 jassids/15 leaves) followed by karanjin (10.66 jassids/15 leaves) and $V$. lecanii (10.91 jassids/15 leaves) treated plots. Next best insecticides were azadirachtin and spinosad with mean population of 12.49 and 13.57 jassids/15 leaves, respectively. $M$. anisopliae, B. bassiana and B.t. were not effective as other treatments in reducing jassids population but were found to be superior over untreated control plots. Highest percentage reduction over control was also found in imidacloprid (76.98\%) treated plots followed by karanjin $(50.02 \%)$ and $V$. lecanii $(48.85 \%)$ treated plots.

After second spray (Table 5), imidacloprid again 

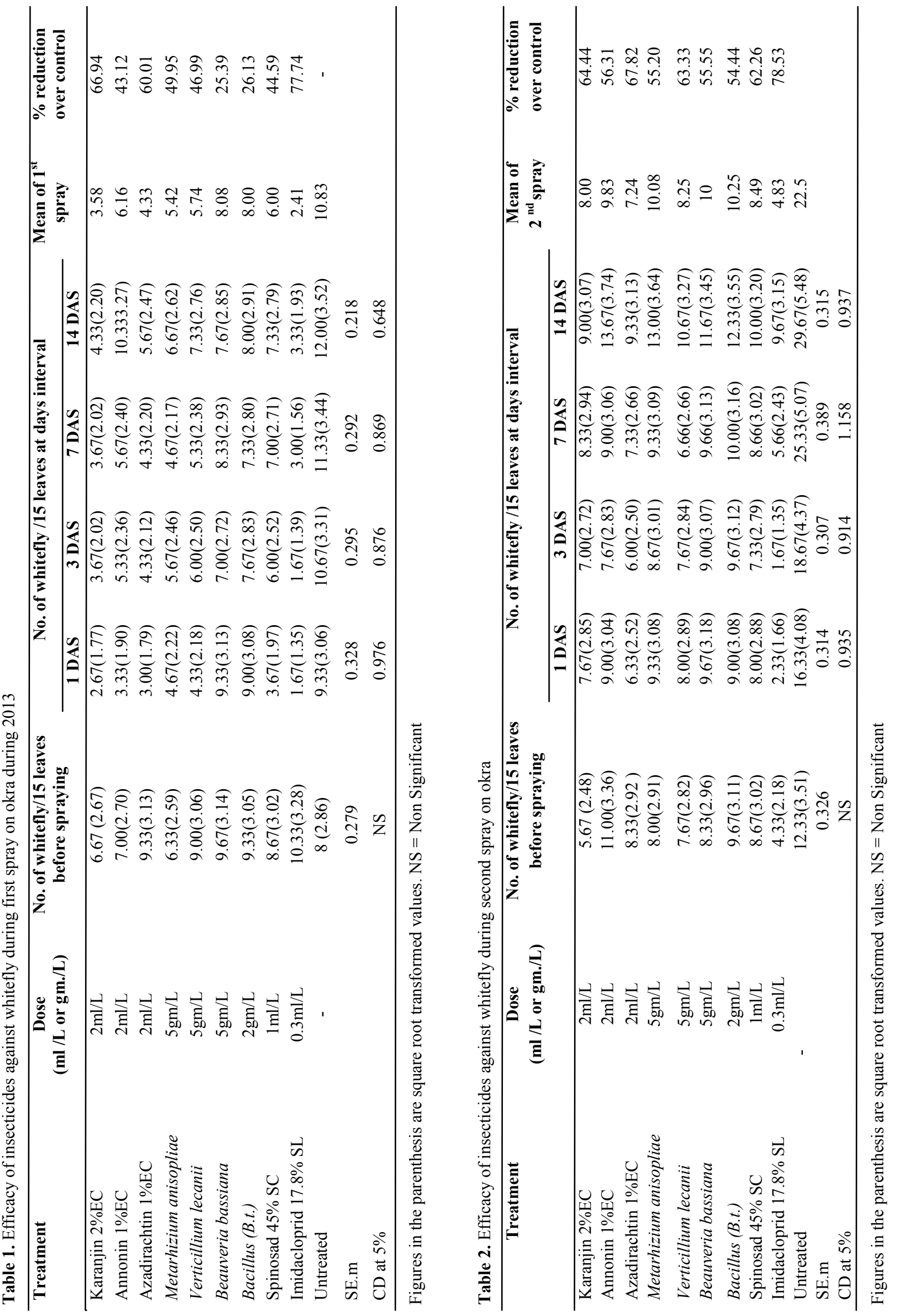

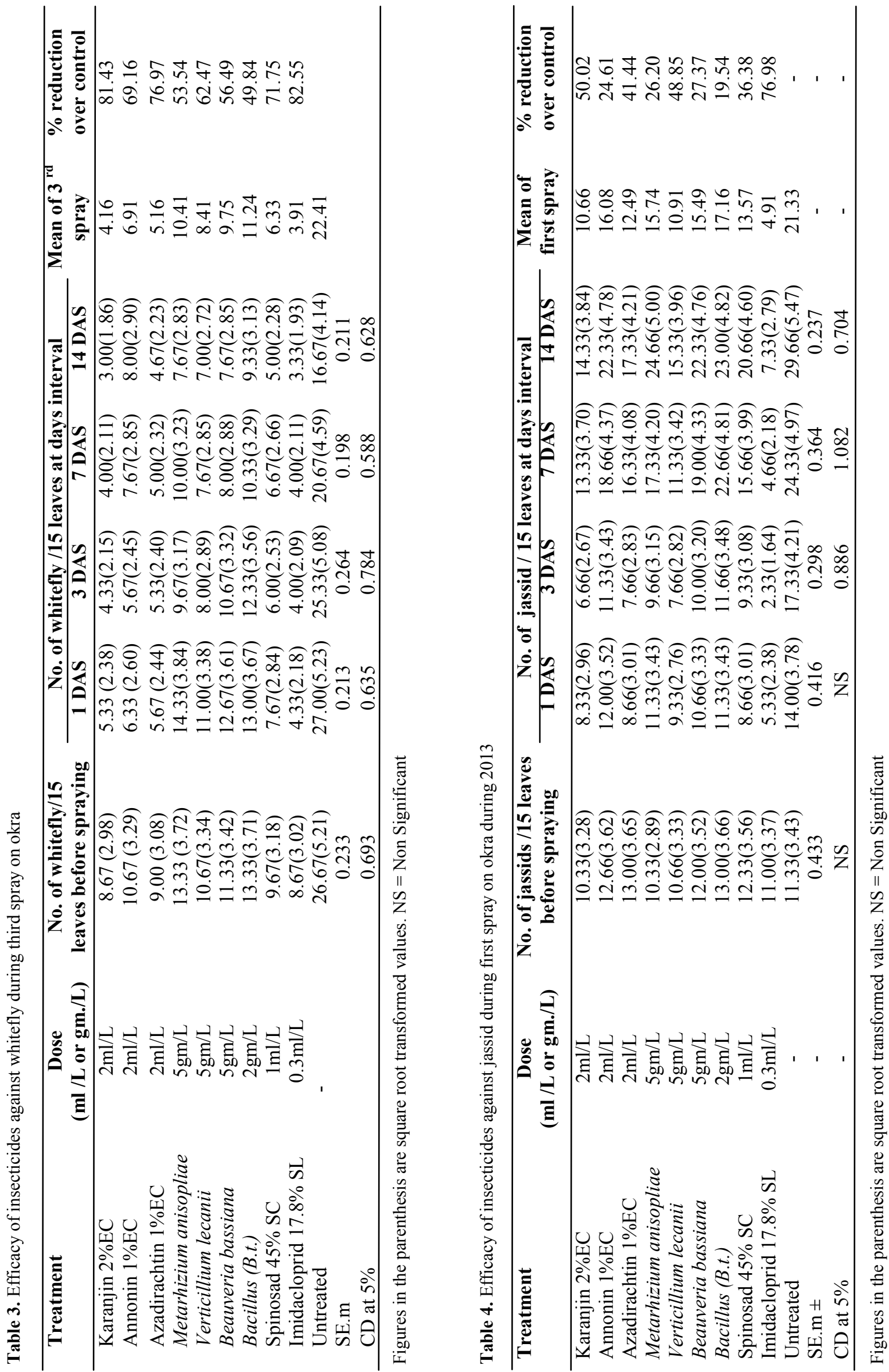

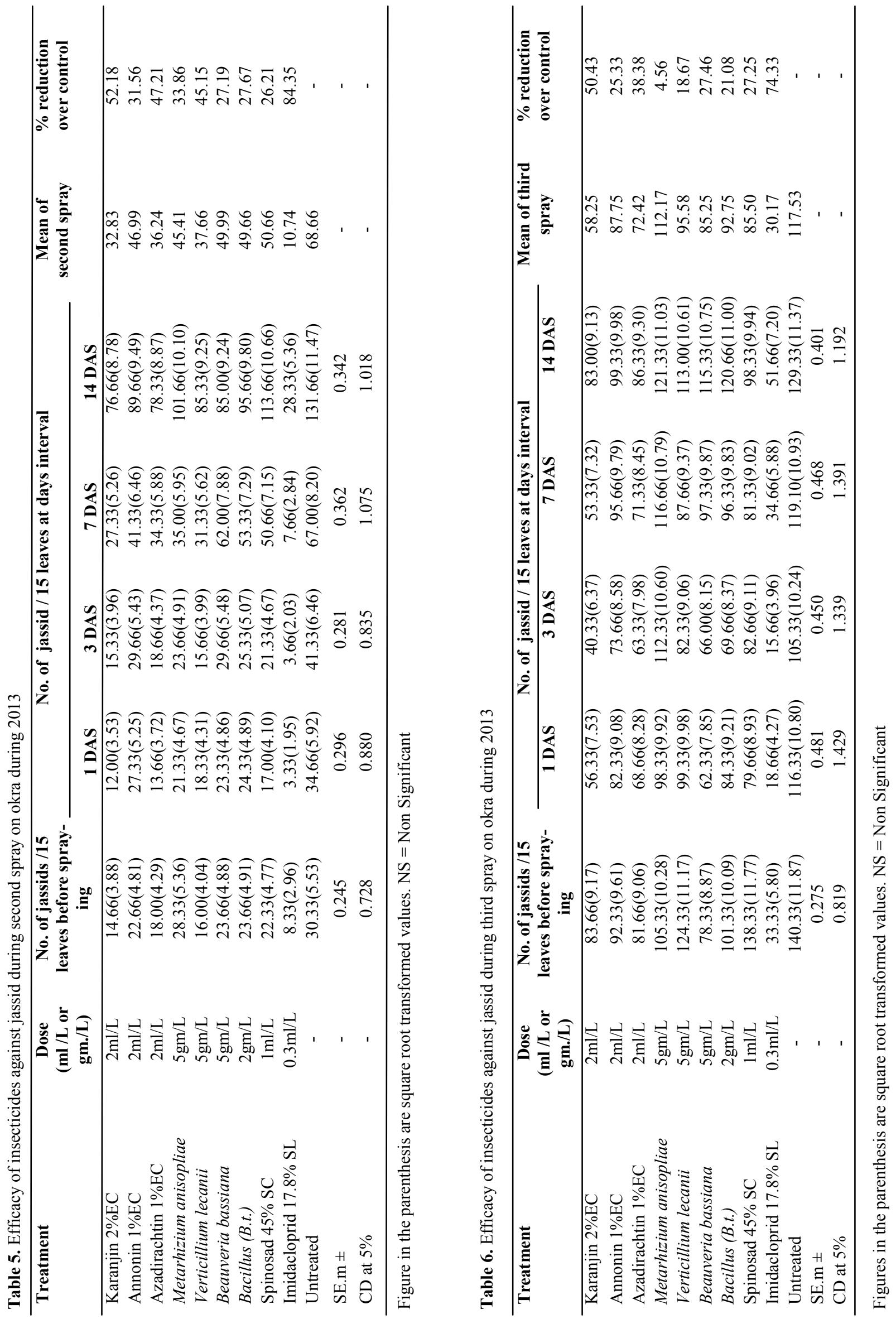
provided best control with lowest mean population of 10.74 jassids/15 leaves followed by karanjin ( 32.83 jassids/15 leaves), azadirachtin (36.24 jassids/15 leaves) and $V$. lecanii (37.66 jassid/15 leaves) treated plots. Similar trend was also observed in percent reduction of jassid population over control. During third spray same trend (Table 6) of efficacy of insecticides against jassids was observed.

After all three consecutive sprays (Table 7), it was found that imidacloprid was recorded lowest mean population of jassid (15.27 jassids/15 leaves) followed by karanjin (33.91 jassids/15 leaves) and azadirachtin (40.38 jassids/15 leaves). Highest percentage reduction of jassid occurred in imidacloprid treated plots (78.55 $\%$ ) followed by karanjin (33.91\%) and azadirachtin (40.38 \%). Annonin, B.t., M. anisopliae and B. bassiana were not effective in reducing population but were superior over untreated control plots.

Results of imidacloprid against jassid ( 15.27 jassids/ 15 leaves) are the analogous with the findings of Mitalilal et al. (2005) who reported that imidacloprid at $40 \mathrm{~g}$ a.i. ha 1 was the best treatment in reducing the jassid population in okra. Bhargava and Bhatnagar (2001) reported that imidacloprid $600 \mathrm{FS}$ at $9 \mathrm{ml} / \mathrm{kg}$ seeds and $70 \mathrm{WP}$ at $10 \mathrm{~g} / \mathrm{kg}$ seeds were found to be promising against jassid (A. biguttula biguttula). Efficacy of karanjin and azadirachtin against jassid are in agreement with the findings of Gurusamy et al. (2000) who found that neem leaf extract was the most effective in reducing jassid and produced highest yield (426 kg/ha) on cotton. Baladaniya et al. (2010) revealed that $V$. lecanii at $7 \mathrm{~g} / 1$ gave significantly higher mortality of okra jassid which is in conformity with the present findings. Effectiveness of $M$. anisopliae against jassid are in disagreement with the results of Maketon et al. (2008) who reported that $M$. anisopliae strain CKM-048 at the dosage of $1.25 \times 10^{13}$ conidia ha 1 showed good controlling efficacy with the $73.33 \pm 10.00 \%$ mortality.

Yield: Yield of okra were varied significantly in different treatment (Table 7). Highest fruit yield of okra was recorded in spinosad $(53.67 \mathrm{q} / \mathrm{ha})$ treated plots followed by B.t. (42.26 q/ha), B. bassiana $(39.28$ $\mathrm{q} / \mathrm{ha})$ and azadirachtin $(37.92 \mathrm{q} / \mathrm{ha})$ whereas, the yield obtained from untreated control plots was $24.81 \mathrm{q} / \mathrm{ha}$.

\section{Conclusion}

The present study on evaluation of the efficacy of different bio-pesticides for eco-friendly management of sucking pests of okra revealed that among the bio pesticides used azadirachtin and karanjin were found very effective against the target pests. Therefore, azadirachtin and karanjin can be an alternative ecofriendly management option for the sucking pests of okra.

\section{ACKNOWLEDGEMENTS}

The authors are highly thankful to Agri Life, Hydera- 
bad, for supplying the most of the bio-pesticides with free of cost to conduct this experiment.

\section{REFERENCES}

Anonymous (2013). Indian Horticulture Database-2013, p301.

Bairwa, D. K.; Sharma, J. K. and Kumawat, K. C. (2006). Efficacy of insecticides, biopesticide and plant products against whitefly, Bemisia tabaci on mothbean, Vigna aconitifolia. Indian Journal of Plant Protection, 34 (2): 210-212.

Baladaniya, R.B.; Kapadia, M.N. and Jethva, D.M. (2010). Dose response of mycoinsecticides against Amrasca biguttula biguttula (Ishida) on okra. Indian Journal of Entomology, 72 (2): 181-182.

Bhargava, K.K. and Bhatnagar, A. (2001). Bioefficacy of imidacloprid as a seed dresser against sucking pests of okra. Pest Management and Economic Zoology, 9 (1): 31-34.

Borkar, S.L.; Sarode, S.V. and Bisane, K.D. (2012). An approach to manage sucking pest complex with plant products in cotton eco system. Journal of Cotton Research and Development, 26 (2): 243-247.

Clement, P. and David, B. V. (1989). Evaluation of certain insecticides for the control of Brinjal and bhendi fruit borers. Pestology, $13: 29-31$.

Gandhale, D. N.; Patil, A.S.; Awate, B. G. and Naik, L. M. (1987). Effective control of Earias sp. On bhindi with synthetic Pyrethroids. Pesticides, $21: 44-45$.

Gurusamy, A.; Ganesaraja, V.; Rajaram, V. and Raveendran, M. (2000). Management of biotic stresses in dryland cotton through bioextracts. Journal of Phytological Research. 13 (1): 105-106.

Hajeri, S.; Dhawan, P.; Rishi, N. and Mehra, R. (2007). Management of tomato leaf curl virus disease by ecofriendly approaches for organic farming in tomato. Haryana Journal of Horticultural Sciences. 36 (3/4): 313-315.

Islam, T.; Omar, D.; Latif, M.A. and Morshed. M. (2011). The integrated use of entomopathogenic fungus, Beauveria bassiana with botanical insecticide, neem against Bemisia tabaci on eggplant. African Journal of Microbiology Research. 5 (21): 3409-3413.

Kashyap, R. K. and Verma, A. N. (1982). Seasonal incidence of spotted bollworm, Earias spp. On Okra at Hissar, Indian Jr. Ecol., 9 (1) : 156-159.

Leeuwen, T.van.; Veire, M. van-de; Dermauw, W. and Tirry, L. (2006). Systemic toxicity of spinosad to the greenhouse whitefly Trialeurodes vaporariorum. Phytoparasitica. 34 (1): 102-108.

Madan, V. K.; Kumari, B.; Singh, R. V.; Kumar, R. and Kathpal, T. S. (1996). Monitoring of pesticides from farm gate samples of vegetables in Haryana. Pesticides Res. Jr., 8 (1) : 56-60.

Mahmood, T.; Mahmood, K. and Naizi, Z. M. (1988). Density variation of leaf hopper on Okra at Islamabad. Pakistan J. Agric. Res., 9 (2) : 195-197.

Maketon, M.; Orosz-Coghlan, P. and Hotaga, D. (2009). Laboratory and field evaluation of Beauveria bassiana for controlling mulberry whitefly Pealius mori Takahashi (Homoptera: Aleyrodidae) in mulberry (Morus alba Linn). Journal of Pest Science. 82 (3): 251-259.

Maketon, M.; Orosz-Coghlan, P. and Hotaga, D. (2008). Field evaluation of metschnikoff (Metarhizium anisopliae) sorokin in controlling cotton jassid (Amrasca biguttula biguttula) in aubergine (Solanum aculeatissimum). International Journal of Agriculture and Biology. 10 (1): 47-51.

Malsam, O.; Kilian, M. and Dehne, H.W. (1998). Metarhizium anisopliae - biological control of the greenhouse white fly (Trialeurodes vaporariorum). Bulletin-OILB/SROP. 21 (4): 125-128.

Mitalilal, K.; Singh, S.P. and Kumari, K. (2005). Bioefficacy of beta-cyfluthrin, lambda-cyhalothrin and imidacloprid against jassid Amrasca biguttula biguttula Ishida in okra. Plant Protection Bulletin. 57 (3/4): 37-40.

Negasi, A.; Parker, B.L. and Brownbridge, M. (1998). Screening and bioassay of entomopathogenic fungi for the control of silverleaf whitefly, Bemisia argentifolii. Insect Science and its Application, 18 (1): 37-44.

Raghuraman, M. and Ajanta, B. (2011). Field efficacy of Imidacloprid on okra sucking pest complex. Indian Journal of Entomology. 73 (1): 76-79.

Rawat, R.R. and Shau, H.R. (1983). Estimation of loss in growth and yield of okra due to Earias spp. Indian Entomology, 35 (3) : 252-254.

Srinivasan, K. and Krishna kumar, N. K. (1983). Studies on the extent of loss and economics of pest management in Okra. Tropical pest management, 29 (4) : 363-370. 